\title{
Could COVID-19 Boost Greece's Village Revival?
}

\author{
Natali DOLOGLOU \\ Metsovion Interdisciplinary Research Centre (MIRC), National Technical University of Athens, \\ Patission 42, 10682 Athens, Greece.
}

\begin{abstract}
In the last decades, Greek villages, especially in mountainous and remote areas, are gradually depopulated and suffer from youth out-migration, school closures and unemployment. During this COVID-19 outbreak, there is an increasing trend of villages as destinations for domestic tourism for short holidays or longer stays. At the same time, this pandemic leads to a significant increase of remote working practices. This article explores the prospect for the revival of traditional villages via an Albergo Diffuso (AD) model with adjustments for both visitors and temporary distance-working residents. We analyze the AD concept as it has been employed in Italy, make minor adjustments to it, and investigate the applicability of such a model in order to overturn the current depopulation of rural and mountain villages in Greece and improve the wellbeing of the local communities. To this end, we present a comprehensive SWOT analysis and discuss the findings. Our approach lays the groundwork for further research that is required to successfully implement $A D$ in mountainous villages.
\end{abstract}

Key words: sustainability; remote working; mountain areas; Albergo Diffuso, workation

\section{Introduction}

COVID-19 has completely disrupted everyday life. Everything has changed and there is great uncertainty in several dimensions. Governmental targets, the business plans of entrepreneurs and even ordinary family plans are largely out of synch with reality. The impact on the economy, at both the local and global scale, will be substantial.

For village communities around the word, the COVID-19 outbreak is one more unsolved issue added to their long list of problems. Nevertheless, and somewhat ironically, this crisis could also work in their favor. It has long been argued that information and communication technologies (ICTs), in particular the Internet, would provide disadvantaged groups and remote rural areas with access to information, services and markets that would otherwise be inaccessible, and that even unemployed people and other vulnerable groups would be assisted in accessing services and developing social contacts through ICT (McQuaid et al., 2004). But progress has been slow so far, especially in remote mountainous villages. Now, due to the pandemic safety measures, there is a rapid adoption of remote working practices as well as the swift digitalization of processes, e-education and e-services.

This creates significant potential for the improvement of the working and living conditions of remote mountain communities. Moreover, and perhaps even more important, this teleworking boom allows regular employees to "escape" into an attractive working environment, away from the mundane workplace. It is not such a big surprise that some mountain villages have now become very popular compared to cities, as they provide a non-crowded, safe and calm environment both for working and leisure.

\footnotetext{
${ }^{1}$ Corresponding author: Natali DOLOGLOU, E-mail: ndolog@mail.ntua.gr. Received on 15 May, 2021. Revised on 25 August, 2021, Published on 10 September, 2021
} 
At the same time, as conventional tourism has practically grinded into a complete halt due to tourism. To make the next step towards a new paradigm, which is also greener and more sustainable, in order to minimize its impact on the climate change.

Could this be the opportunity for a revival of Greek villages? Is now the time to enhance living conditions in rural areas and minimize the decline of population? To answer these questions, this study gathers facts, analyses key factors and suggests a methodology for investigating the suitability of mountain villages to implement the Albergo Diffuso (AD) model, which was originally adopted in Italy. We start by setting the context and presenting the main features of agritourism and the AD model. Then, we combine these facts in order to discuss whether now is the right opportunity to develop $\mathrm{AD}$ in Greek villages and to perform a comprehensive SWOT analysis that identifies possible options and pitfalls.

This work is based on empirical and multidisciplinary literature data that estimates the current reality in Greek mountain villages, aiming to identify and analyze the particular local and external factors related to an AD development. It is useful for researchers, tourism experts, local communities, decision makers and stakeholders, giving an overview of the AD potential in Greece.

the pandemic, there is a strong belief that now could be the right time to re-think and re-start

\section{Literature review}

\subsection{Mountain villages}

The recent awareness campaign of FAO (2020) for the importance of mountains and mountain biodiversity, addresses some of the threats that mountainous areas face: climate change, unsustainable farming practices, commercial mining, logging and poaching, biodiversity loss, ecosystem degradation, land use and land cover change, natural disaster. In addition, mountain villages typically have poor road networks, few or no public services and no recreational infrastructures. Schools, if any, are understaffed and with only a handful of students. The residents, who are mostly elderly, do not have easy access to the health system. In addition, the sometimes bad or even extreme weather conditions and the increased energy needs for heating and transportation.

All these issues can lead to out-migration and to the abandonment of practices and ancient traditions, which have sustained biodiversity and cultural diversity for generations. It is documented that just like biodiversity increases the resilience of natural systems, in a similar way, cultural diversity can increase the resilience of social systems. Unfortunately, this analogy also holds for their extinction. Just like lost biodiversity cannot be re-created, if cultural diversity is lost then it cannot be reborn (Pretty et al., 2009).

It is clear that the problem of mountain village desertification is complex. These fragile communities need - now more than ever - a carefully designed plan for a better future. Notably, for some mountain regions the living conditions are not a problem, but an advantage: smooth life rhythm, few people, contact with nature, low living cost. In the study of Zachos (2012), involving 400 urban residents, there was a positive mood to live in the mountains (54\%) provided the professional conditions were comparable to that of a city. Yet, this number may be deceiving, as the majority of the respondents are not familiar with the harsh reality in mountain villages.

\subsection{Agritourism}

Agritourism is a sustainable form of tourism, which offers authentic hospitality and 
connection with the local community, agricultural production and culture. More specifically, according to the definition adopted in Greece, agritourism has the aim to: a) help the visitor to experience the rural areas, farming activities, local products, traditional gastronomy and daily life, cultural elements and original features of the area; b) bring visitors in touch with nature and outdoor activities, in which they can participate, be entertained and feel the joy of touring, learning and discovery; c) mobilize the local productive, cultural and developmental forces thus contributing to sustainable environmental, economic and social development of rural areas (ELOT, 2003).

UNEP estimates that mountain destinations attract around 15-20\% of global tourism (Debarbieux et al., 2014). However, these are distributed unequally around the globe. Some mountain villages face marginality and poverty, while others face the negative impacts of mass tourism. Tourism is a complex and multidimensional phenomenon, and the sector's value chain transcends and influences the economics of other sectors, such as agriculture, manufacturing, construction, transport (Adiyia and Vannesstte, 2018) and services. Therefore, agritourism has the potential to foster economic development in remote and isolated regions, which would otherwise be abandoned resulting to significant loss of cultural identity.

\subsection{The Albergo Diffuso concept}

The Albergo Diffuso (AD) is an innovative hospitality model conceptualised by Professor Giancarlo Dall'Ara in the early 1980's as a way of reviving small traditional and historical villages. AD was formally acknowledged in Sardinia with a specific regulation in 1998 and special legislation supports the idea in practice. The "Albergo Diffuso" label has been established as a trademark and is an indication that the hotel follows certain specifications, as set by the Alberghi Diffusi National Association (Adi). According to Adi (n.d), there are 89 AD hotels dispersed in all regions of Italy. Notably, the model has been imitated by other countries such as Croatia, Switzerland and Japan.

According to Dall' Ara (2019), an AD embodies three things at a time: 1) it is a unique hospitality concept, as it does not require any building, just organizing what is already there; 2 ) it is a hotel that is not built, but guests can use all hotel services; 3) its units are located among residential houses, so that the guest can experience being a temporary resident as opposed to a mere tourist. Dall' Ara and Villani (2015) describe the main features of AD, which include the joint management and the presence of a hosting community, so that the relationship between users and residents is ensured. Soszyński et al., (2018) argue that spatial factors may be important for quality of life and positive relationships among local residents and tourists. Actually, $\mathrm{AD}$ is an accommodation facility integrated in the territory, where the community is the main element of the hospitality services being provided.

Vallone et al., (2013) present data from two AD case areas in Italy, documenting that hospitality services do not differ from those of a typical hotel, while the activities offered have much in common with agritourism, including, for example, wine tasting, cooking lessons, arts lessons and guided hikes in National Parks. The findings of Paniccia and Leoni (2017:1) show that $\mathrm{AD}$ can be considered as a new sustainability-oriented hospitality model, which positively affects the competitiveness of the destination by creating synergies with its territory. In conclusion, the AD model is not just about accommodation, but an opportunity to regenerate and protect, in an inexpensive way, the entire economic, social and cultural local system (Tagliabue et al., 2012; Cucari et al., 2019); Di Gregorio, 2017) as cited in Giampiccoli and 
Mtapuri, (2020:8), so we can say that AD is an example of the evolution of (rural) tourism (De Montis et al., 2015) as cited in Cucari et al., (2019:105) and agritourism.

\subsection{Remote working in the COVID era}

Professional conditions have changed unexpectedly fast due to the promotion of teleworking in order to combat the COVID-19 crisis. In Europe, an average of $37 \%$ of the working population reported working at home in April 2020 because of the pandemic, while homeworking rates are up to $60 \%$ in Finland and above 50\% in Luxembourg, the Netherlands, Belgium and Denmark (Eurofound, 2020). Further research from Felstead and Reuschke (2020) on teleworking companies in the UK, estimated that $40.9 \%$ of homeworkers were able to work in June 2020 as efficiently as a few months earlier from their usual workplace. The same study reports that $88.2 \%$ of the employees who worked at home during the lockdown would like to continue working at home in some capacity. Before this pandemic, the adoption of teleworking practices was much slower than anticipated, due to various human, social and organisational factors, including basic human factors associated with people's needs to meet other people face to face (Eurofound, 2017; Vilhelmson and Thulin, 2016; Eurofound, 2010; Rasmussen and Corbett, 2008).

According to Belzunegui-Eraso and Erro-Garcés (2020), the pandemic may significantly upgrade the concept of teleworking. Not just as an occasional, ad-hoc measure to handle environmental or health catastrophes, but also as a strategy to reduce the cost of infrastructure, contain contamination, minimize mobility-related climate change as well as to generate a favourable climate for combining work and family life. One more reason why remote working could be established more firmly is that companies have now paid the fixed costs of learning how to make remote working effective, and are motivated to capitalize on this investment by having a larger number of remote working employees (Bartik et al., 2020). In fact, as reported in the same study, companies should have been allowing more remote work before COVID-19, but failed to do so due to ignorance or coordination issues. The pressure of the obligatory lock downs has forced companies to react fast in order to resolve these problems so that their employees can work from home as efficiently as possible.

Workationing (verb) means methodically bouncing to different locations around the world, working along the way. Ideally, staying in one place long enough to get a feel for the local flavour and get a specific work project done (workationing.com). These travellers / digital workers, referred as digital nomads, are estimated before the pandemic around 4.8 million in the US alone (MBO Partners, 2018). The MBO Partners (2018) study found that two-thirds of digital nomads are male, while over half are older than 38 years, with a reported income that spreads from less than $\$ 10.000$ per year (38\%) to $\$ 75.000$ or more (16\%) (MBO Partners, 2018). It is therefore clear that digital nomads are not an easily identifiable demographic group. Moreover, there is a lack of workation data in the related bibliography, which is typically multidisciplinary and eclectic (Pecsek, 2018). However, we are convinced that the actual numbers of digital nomads will increase due to the changing working patterns caused by COVID-19. Already, all around the world there is a growing number of countries offering digital nomad visas, settlement facilities and even tax incentives.

\subsection{Re-design tourism}

Some entrepreneurs are expecting that by the end of COVID-19 pandemic tourism will revert back to normal with "business as usual". However, pressure on the most visited locations 
comes with risks such as overcrowding, unsustainable demand for natural and cultural resources, and possible disruptions to social identity and community life (UNWTO, 2020).

In the past, scholars suggested tourism degrowth or slow-down as a responsible reaction to climate change. This seemed practically impossible to achieve at the time. Now, due to the pandemic, this degrowth is actually here. It is argued that COVID-19 is both a public health crisis and a real-time experiment in downsizing the consumer economy, representing the beginning of a transition towards sustainable consumption (Goffman, 2020; Ateljevic, 2020; Brouder, 2020) as well as the opportunity to reset and reshape tourism in a more sustainable way (Hall et al., 2020; Cheer, 2020; Higgins-Desbiolles, 2020) as cited in Seyfi and Hall (2020).

However, according to Christakis (2020), lessons from the past showed that "periods of plague-driven austerity have often been followed by periods of liberal spending". Therefore, if we do not change policy, unsustainable tourism consumption may be back, even stronger than before the pandemic. Mtapuri, and Giampiccoli (2019) notice that sustainability should be embedded in the general definition of tourism. They claim that this is not an option but an imperative in modern times. The challenge is now to collectively learn from this global crisis in order to accelerate the transformation of sustainable tourism (Gössling et al., 2021).

\subsection{Is this an opportunity for village revival in Greece via an AD model?}

During this pandemic, a significant change has been made to some rural areas, particular to the ones located near big cities. There is an increased need of city residents to escape to villages and nature, where some of them also have their secondary homes. After the first pandemic wave, and given the general travel restrictions imposed on citizens to contain the pandemic, many people have changed their travel habits, shifting from long weekends in other countries/cities/overcrowded destinations to domestic rural destinations. This comes in line with Rauniyar et al., (2020) and Christou and Sharpley (2019), who argue that as tourists want to spend less time in their journey, agritourism has now become a major form of tourism, where a majority of tourists are from nearby cities.

There are no officially published data yet available for Greece regarding the movement of urban dwellers towards villages. Still, there are some signs of a trend. For instance, according to media reports, there is an increasing tourism demand in Arcadia's mountains (Zefkili, October 26, 2020), in the Vermio mountain (Kazantzidou, June 24, 2020) and Zagorochoria in the Pindos range (Chiotopoulou, October 18, 2020). Also, as a more striking example, the village of Arachova in the Mountain of Parnassos, is completely booked out for the first time even before the economic crisis struck Greece in 2010 (Goulas, October 18, 2020). There is no empty house to rent for the season to come. Moreover, according to toll track records, just a few days before the second lockdown (November 7, 2020), almost 155.000 cars left from Athens, a number that is comparable to a Christmas holiday exit. Most of these cars have not returned yet - Greece is in a lock down state as we write these lines.

In general, vacant homes are associated with the degradation of an area. While they were not initially treated as a problem, but as a symptom of the 'disinvestment' of the area, they are now increasingly considered as both, as they are contributing to a vicious cycle of decline (Accordino and Johnson, 2000). During the last decade, due to the economic crisis of Greece, the maintenance of a residence was considered a luxury for many, not to mention secondary and holiday homes. Ownership gradually became unattractive. High taxation on properties, inability to rent or collect rents, the fall of sales prices and the absence of buyers-lead to a deadlock. 
Recently, there are signs of change: secondary homes are now being maintained and inhabited more often. Even though the Greek economy is not doing well and people lose income or even their jobs because of the pandemic, they do invest in secondary property maintenance, as a reaction to create a shelter/refuge. Residences in villages provide safety compared to the crowded cities against COVID-19, and for some also a cosy working space when there is a teleworking possibility. Therefore, there is a trend of revival and an increasing demand of housing in villages.

Still, offering short/long accommodation to people who wish to escape to villages is a complex task, raising sustainability issues and requiring the motivated involvement of the local communities. Cooperative projects, where the local residents take control of tourism development in their area in a democratic and egalitarian way that respects not only the needs of the newcomers but also the local priorities and lifestyle, are highly desirable. This study focuses on the Albergo Diffuso (AD) model, which seems to be particularly suitable for this purpose.

In Greece, hamlets are scattered all over this 70\% mountainous country, from the Massive Pindos range to the widely dispersed 227 inhabited islands. About 924 villages are characterized as "traditional" by the corresponding Ministry, now called Ministry of the Environment and Energy. Clearly, there are numerous choices to consider as possible venues for an AD establishment (Figure1).

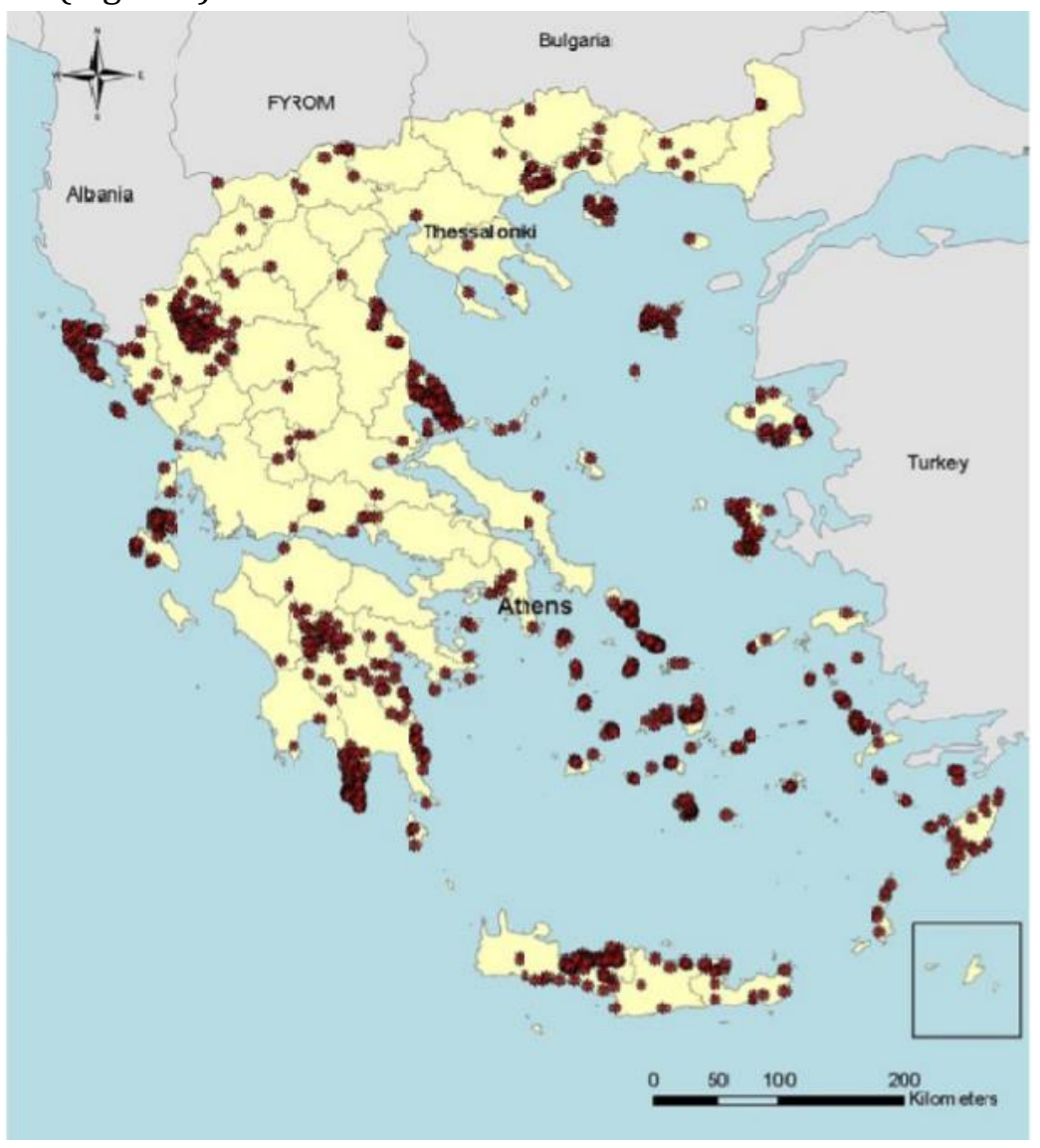

Figure 1. Map of traditional villages in Greece (Pozoukidou, and Papageorgiou, 2013: 502)

Largely due to the pandemic, even people in remote areas who have not previously used the Internet, have now learned how to communicate with their loved ones via teleconferencing tools and how to pay bills online. It is worth noting that during lock downs it was the first time where Greek citizens were able to complete and digitally sign an authorization form 
electronically, without having to get physical stamps and signatures from the corresponding authorities. Now, it is also possible to get an electronic drug prescription without actually visiting the responsible physician. Moreover, online learning and training is on the rise. There is now wide variety of different courses, seminars and webinars on almost every perceivable topic. Access is easier than ever, also for young people living in mountain villages, provided they have Internet connectivity and a computer or just a smartphone. The long identified role of ICT as a key driving force providing the means to operate and do business anywhere and anytime (Fougere and Behling, 1996), is now indeed in play.

Before the pandemic, Greece had a typical "old school" working environment, with a prevalent "must go to the office every day and leave late from the office after the boss" attitude among employees and employers. Unlike many other European countries, before COVID-19 there were hardly any companies that had a serious remote working policy. As documented above, remote working can be quite productive and several people actually find it an attractive alternative. A preliminary survey of KPMG (2020) in Greece shows that $67 \%$ of employees who telework during pandemic were positive or very positive to work remotely on a permanent basis. Based on 2019 data, the Centre of Planning and Economic Research (2020) estimates that $32.8 \%$ of jobs in Greece are compatible with a remote working mode. Therefore, remote working could be a golden opportunity to reduce the unemployment in mountain villages.

In addition, the typical advantages of big city life have been canceled due to the COVID-19 restrictions. There are no open theatres, no fancy restaurants and clubs, no glamourous social events. The city feels dead. To make matters worse, the disadvantages of city life are becoming even more pronounced: difficulties in transportation, queue lines everywhere, social distancing, insufficient private space, fear and anxiety. The life in a village seems more attractive than ever before.

Under these inconvenient circumstances, some people will consider moving away for a week or more to enjoy the calm rhythm of a village while teleworking. However, it is important to keep in mind that telecommuters would not move far away from work, to another town or village, just because they are able to work remotely. As Ory and Mokhtarian (2006) document, telecommuting simply enables a movement that is anyway desired for other reasons, e.g., to accommodate household needs, to obtain a larger and/or cheaper home, to be near scenic locations, and so on. Therefore, for the few that really want to escape to villages, we consider remote working as a facilitator, enabling them to move in an $\mathrm{AD}$ and feel like a local, while remote working, for a short or longer term. Note that even a few people can give life to the village and create some decent profit for the locals, provided the concept is properly designed so as to ensure low-key continuity as opposed to a one-off flare that will quickly fade in time.

For the above reasons, as an extension to the original features of the AD model, we propose to add features that will explicitly encourage and foster remote working. We will refer to this extended version as AD+ (Albergo Diffuso Plus) to underline the difference vs the traditional AD model. We suggest that $\mathrm{AD}+$ should provide: fast and free Internet connectivity to all residents, configuration of an office room/corner in the $\mathrm{AD}$ house or a separate building in the village designated to be used as a working hub for the visitors and locals. Services such as printing facilities, courier services could be centralized to the working hub or the reception unit. In addition, $\mathrm{AD}+$ should involve green technology in buildings and operations, for example bioclimatic architecture, energy and water consumption, recycling and up-cycling, local products use, following specific standards according to a proper eco label scheme for 
agritourism in Greece, such as Green Key (Foundation for Environmental Education, n.d.) or the EETLS standard (European Ecotourism Network, n.d.). Last but not least, as a fundamental precondition for the development of an $\mathrm{AD}+$, the idea and initiative has to originate from the local community itself, with the residents being properly informed so that they know the advantages as well as the challenges and the peculiarities of such a project. Needless to say, but not to be taken for granted, this can only succeed if local stakeholders embrace the concept and cooperate with each other in a smooth way in order to implement it.

\section{Methodology}

This article conducts a comprehensive SWOT (strengths, weaknesses, opportunities, threats) analysis. SWOT is a valuable brainstorming and decision-making tool, which has been applied in a wide range of fields. Several academics have conducted SWOT analysis to reveal issues related to tourism studies, such as: hotel industry (Hung, 2015); medical tourism development (Kim et al 2013); heritage tourism (Lak et al., 2020); rural tourism development in mountain regions (Lun et al., 2016); ecotourism planning decision in protected areas (Demir et al., 2016); exploring astrotourism for sustainable rural tourism development (Jacobs et al., 2020); climate change and winter tourism in mountain communities (Bonzanigo et al., 2020).

A SWOT analysis can capture various aspects of a tourist venture: (i) it identifies the associated favourable and unfavourable features; (ii) it guides the formulation of subsequent steps accordingly; (iii) it helps to clarify future directions in the planning process in order to establish priorities; (iv) it supports the design of the most effective course of action in terms of strategic decisions to be taken (Patnaik and Poyyamoli, 2015). Based on the results of such an analysis, suitable strategies can be developed, which build on the strengths, eliminate the weaknesses, seek to exploit the opportunities and counter the threats identified (Dyson, 2004). These strategies should be oriented towards making the best use of advantages while at the same time removing any possible disruptions which may be caused by the development of tourism (Goranczewski and Puciato, 2010).

The AD model advocates a strong relationship, interconnection and interdependence with the local community, culture and wider environment of the target area, which can have a very significant impact on the services provided to visitors. Also, by design, it strikes a balance between the use of local resources and offered tourist services, without fiercely exploiting the former in order to unconditionally promote the latter. To this end, it is of paramount importance to conduct a thorough analysis, across the different dimensions of such a venture. Active local residents should be the ones who plan the village's pathway to Worth Living Integrated Development, a development which satisfies the need for this comprehensive dialectical harmony, symmetry and balance in the process of completion of development with the economic, social, political, and cultural and technological dimensions (Rokos, 2003; Koroneos and Rokos, 2012).

In this article, we present a multi-dimensional SWOT analysis, which identifies key factors representing the strengths, weaknesses, opportunities and threats from the perspective of a village considering an $\mathrm{AD}+$ undertaking. These factors are analyzed in the dimensions which define the core of Worth Living Integrated Development: social, economic, environmental, political, technological (including infrastructures) and cultural, tightly-coupled with the reality of the specific area in question and in context of its various external forces. Focus is on the AD+ concept described earlier, which extends the traditional AD model to explicitly consider workationing visitors in addition to the usual short-term visitors who are the target of typical 
AD. This analysis is based on subjective views on data that is gathered from the literature (Dropulić et al., 2008; Pansiri, 2014; Di Gregorio, 2017; Dologlou, 2017; Demir et al., 2016; Li et al., 2016; Cucari et al., 2019; Giampiccoli and Mtapuri, 2020).

\section{Results}

The results of the SWOT analysis are presented in Tables 1-6. We briefly discuss some of the aspects in the sequel.

Table 1. SWOT analysis of a hypothetical Greek mountain village considering an AD+ undertaking. Environmental Dimension.

\begin{tabular}{|c|c|c|c|c|}
\hline & Strengths & Weaknesses & Opportunities & Threats \\
\hline 胥 & $\begin{array}{l}\text { - Unique } \\
\text { natural } \\
\text { environment } \\
\text { of the area } \\
\text { - Air quality } \\
\text { - Climate }\end{array}$ & $\begin{array}{l}\text { - Waste management } \\
\text { - Operational difficulties } \\
\text { - High energy } \\
\text { requirements for heating } \\
\text { and transfer } \\
\text { - Lack of use of renewable } \\
\text { energy technology } \\
\text { - Lack of local } \\
\text { environmental } \\
\text { awareness }\end{array}$ & $\begin{array}{l}\text { - Promotion and } \\
\text { conservation of } \\
\text { natural environment } \\
\text { - Outdoor and } \\
\text { adventure tourism } \\
\text { opportunities } \\
\text { - Training and } \\
\text { awareness for } \\
\text { environmental } \\
\text { conservation }\end{array}$ & \begin{tabular}{|l|} 
Failure of \\
environmental \\
awareness and \\
natural \\
environmental \\
management \\
- Uncontrolled tourist \\
traffic \\
- Natural extreme \\
phenomena \\
\end{tabular} \\
\hline
\end{tabular}

Table 2. SWOT analysis of a hypothetical Greek mountain village considering an AD+ undertaking. Social Dimension.

\begin{tabular}{|c|c|c|c|c|}
\hline & Strengths & Weaknesses & Opportunities & Threats \\
\hline $\begin{array}{l}\text { 중 } \\
\text { ச }\end{array}$ & $\begin{array}{l}\text { - } \text { Multiple } \\
\text { employment } \\
\text { - } \text { Calm rhythms } \\
\text { - } \text { Active } \\
\text { expatriates } \\
\text { - } \text { Authentic } \\
\text { hospitality } \\
\text { - } \text { Safety }\end{array}$ & $\begin{array}{l}\text { - Lack of awareness } \\
\text { about the cultural } \\
\text { value of their area } \\
\text { - Ignorance about the } \\
\text { AD model } \\
\text { - Inability to } \\
\text { cooperate } \\
\text { - Demographics } \\
\text { - Lack of basic } \\
\text { services for locals } \\
\text { and visitors }\end{array}$ & $\begin{array}{l}\text { - Participatory processes } \\
\text { and top down decision } \\
\text { making } \\
\text { - Social cohesion } \\
\text { - Training on technology } \\
\text { - Establishment of } \\
\text { cooperatives and networks } \\
\text { in local, regional and } \\
\text { national level to run an AD } \\
\text { endeavour } \\
\text { - Population increase }\end{array}$ & $\begin{array}{l}\text { - Lack of young } \\
\text { educated citizens } \\
\text { - Lack of active } \\
\text { citizens } \\
\text { - Local tensions } \\
\text { and conflicts of } \\
\text { interest } \\
\text { - Difficulties in } \\
\text { collaboration } \\
\text { - Insufficient } \\
\text { training }\end{array}$ \\
\hline
\end{tabular}

Table 3. SWOT analysis of a hypothetical Greek mountain village considering an AD+ undertaking. Economic Dimension.

\begin{tabular}{|c|c|c|c|c|}
\hline & Strengths & Weaknesses & Opportunities & Threats \\
\hline 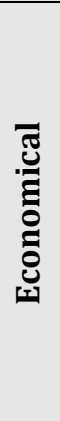 & $\begin{array}{l}\text { - Family and } \\
\text { collective } \\
\text { businesses } \\
\text { - Local products } \\
\text { - Existing } \\
\text { infrastructures } \\
\text { and services }\end{array}$ & $\begin{array}{l}\text { - Limited } \\
\text { entrepreneurship } \\
\text { - Limited access to } \\
\text { funds } \\
\text { - High cost of energy } \\
\text { - Initial cost of an AD } \\
\text { investment } \\
\text { - Inexperience in the } \\
\text { tourism sector } \\
\text { - Lack of experts }\end{array}$ & $\begin{array}{l}\text { - Local income } \\
\text { support } \\
\text { - Utilization and } \\
\text { improvement of } \\
\text { existing } \\
\text { infrastructure and } \\
\text { services } \\
\text { - Increasing demand } \\
\text { of local products } \\
\text { - Possible funding }\end{array}$ & $\begin{array}{l}\text { - Internal and international } \\
\text { tourism competition } \\
\text { - Inability to collect funds } \\
\text { - Exclusive involvement in } \\
\text { tourism } \\
\text { - Continuous changes of } \\
\text { tax regimes } \\
\text { - High cost of living for the } \\
\text { locals (rise of prices due } \\
\text { to tourist demand) }\end{array}$ \\
\hline
\end{tabular}


Table 1. SWOT analysis of a hypothetical Greek mountain village considering an AD+ undertaking. Cultural Dimension

\begin{tabular}{|c|c|c|c|c|}
\hline & Strengths & Weaknesses & Opportunities & Threats \\
\hline 葛 & $\begin{array}{l}\text { - Valuable cultural } \\
\text { heritage } \\
\text { - Traditional } \\
\text { architecture } \\
\text { - Yearly festivities } \\
\text { and cultural } \\
\text { activities }\end{array}$ & $\begin{array}{l}- \text { Traditions and } \\
\text { culture are not } \\
\text { passed on to the } \\
\text { next generation } \\
\text { - } \text { Copy of city trends }\end{array}$ & $\begin{array}{l}\text { - Training and } \\
\text { awareness for cultural } \\
\text { conservation } \\
\text { - Promotion of local } \\
\text { culture } \\
\text { - Enrichment of cultural } \\
\text { activities offered }\end{array}$ & $\begin{aligned} \text { - } & \text { Foreign inputs like } \\
& \text { city trends, culture } \\
& \text { alteration } \\
\text { - } & \text { Loss of traditional } \\
& \text { professions } \\
\text { - } & \text { Loss of traditional } \\
& \text { knowledge }\end{aligned}$ \\
\hline
\end{tabular}

Table 2. SWOT analysis of a hypothetical Greek mountain village considering an AD+ undertaking. Technological Dimension

\begin{tabular}{|c|c|c|c|c|}
\hline & Strengths & Weaknesses & Opportunities & Threats \\
\hline 를 & $\begin{array}{l}\text { - Technology } \\
\text { penetration } \\
\text { - New } \\
\text { telecommunicati } \\
\text { on networks }\end{array}$ & $\begin{array}{l}\text { - Unfamiliarity } \\
\text { with technology } \\
\text { - Lack of internet } \\
\text { connectivity }\end{array}$ & $\begin{array}{l}\text { - Lift digital isolation } \\
\text { - Workation } \\
\text { - Use of technology } \\
\text { innovation in } \\
\text { building restorations }\end{array}$ & $\begin{array}{l}\text { - Inability to use } \\
\text { technology } \\
\text { - Gap between those who } \\
\text { know to use technology } \\
\text { and those don't }\end{array}$ \\
\hline
\end{tabular}

Table 3. SWOT analysis of a hypothetical Greek mountain village considering an AD+ undertaking. Political Dimension

\begin{tabular}{|c|c|c|c|c|}
\hline & Strengths & Weaknesses & Opportunities & Threats \\
\hline 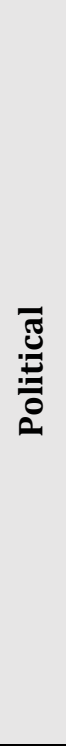 & $\begin{array}{l}\text { - Bottom up } \\
\text { approach by } \\
\text { small group of } \\
\text { residents who } \\
\text { has trust and } \\
\text { affinity } \\
\text { - Experience } \\
\text { learned from } \\
\text { AD } \\
\text { establishment } \\
\text { in Italy }\end{array}$ & $\begin{array}{l}\text { - } \text { Road network in bad } \\
\text { conditions } \\
\text { - Poor implementation of } \\
\text { rural plans for } \\
\text { reconstruction and } \\
\text { development } \\
\text { - } \text { Insufficient destination } \\
\text { marketing } \\
\text { - Lack of statistical data } \\
\text { - Lack of cooperation to } \\
\text { local, regional and } \\
\text { national level } \\
\text { - Lack of social services } \\
\text { - No special legislation for } \\
\text { AD } \\
\text { - Bureaucracy }\end{array}$ & $\begin{array}{l}\text { - Implementation of a } \\
\text { long-term policies } \\
\text { - Adoption of legislative } \\
\text { framework for rural } \\
\text { tourism and AD } \\
\text { establishment } \\
\text { - Create conditions and } \\
\text { facilitate remote job } \\
\text { positions } \\
\text { - International } \\
\text { cooperation towards a } \\
\text { remote working } \\
\text { - Existing financial } \\
\text { instruments for rural } \\
\text { and mountainous } \\
\text { areas } \\
\text { National plan for rural } \\
\text { development }\end{array}$ & 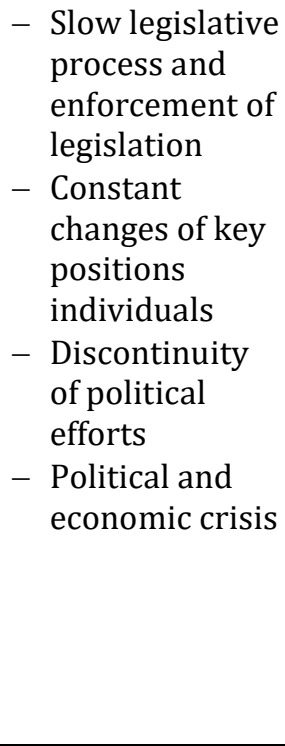 \\
\hline
\end{tabular}

\subsection{Strengths}

The authentic and unspoiled nature, the cultural and traditional assets of the area, climate conditions and qualitative local products can provide an ideal venue for an AD establishment (tables 1-6).

Summers are cooler compared to Greece's coastline, while winters are mild and shorter compared to e.g. central Europe, so mountain villages can be ideal destinations for some, all year round. In addition, some Greek villages have ideal geographical position for daily trips to the surrounding areas, even coastal. Mountain local products, such as meat and dairy products, arts and crafts gain more and more recognition for their properties and quality. The small traditional restaurants and coffee shops, contact with nature, culture and the everyday life in a village, and the authentic hospitality offer a unique experience for visitors. Safe and secure environment 
compared to most cities, enhance the relaxation and the stress-free feeling for residences and visitors.

\subsection{Weaknesses}

The weaknesses are related mainly to environment, society, economy and policies, as shown in the relevant column of tables 1, 2, 3 and 6. The cost of an AD+ establishment, although relatively low compared to typical mass-scale tourism ventures, is an issue if the local community does not have access to funding and has no solid tourism and/or entrepreneurship experience. Unfortunately, this is quite likely to be the case, as the residents of a mountain villages are mostly elderly and of basic educational level. This could lead as well to lack of visionary people to drive and support the participatory initiatives of an $\mathrm{AD}+$ project. In addition, many villages lack key infrastructures and services that are required in order for such a project to succeed.

The mountains of Greece have significant natural and cultural assets like national Parks and cultural heritage monuments. Although these provide added value, various limitations and restrictions in land use and traditional practices often lead to lengthy bureaucratic procedures, operational inefficiency and tensions between residents, entrepreneurs, local authorities and agencies (e.g. National Park Managerial Agencies).

In addition, everyday life can be quite difficult even regarding basic services and facilities. In some mountain villages there are no pharmacies, no banks, no health centres or even no proper super markets. Locals, in the best scenario, uses services of neighbouring villages/cities. In the worst case, they have to travel long distances in order to use these basic services.

\subsection{Opportunities}

The opportunities for mountain villages regarding the application of an $\mathrm{AD}+$ model are summarised in tables 1-6. Through AD+ it becomes possible to regenerate the village, create new jobs, boost multi-employment, strengthen family and collective businesses, accelerate the use of technology, reduce seasonality and stimulate the local community and economy. At the same time, this can give life to the traditional residential asset of the village, instead of this being gradually abandoned and eventually lost irreversibly, along with the local culture and tradition. It may also be possible to gain funding under national or EU programmes in order to enhance the facilities and services of the village and/or funding for $\mathrm{AD}+$ development.

Fast Internet is a prerequisite for $\mathrm{AD}+$, so this creates the first step to lift digital isolation. Then, remote training practices, online courses, and even telemedicine could possibly be developed, if the locals are willing to interact and if others existing constrains are surpassed. Workationing visitors, native or outlanders is the target group for $\mathrm{AD}+$, and in that direction a legislative framework for rural tourism, AD establishment, remote working and a long term policy to strengthen rural societies must be created. Respectively, it is an opportunity for international cooperation towards a remote working rotational program with countries, agencies and companies that are willing to offer an alternative environment to their employees.

\subsection{Threats}

Tables 1-6 list the main factors posing a threat to such a venture. The political and economic crisis in Greece, inability to use technology, lack of funds, competition with other tourism 
destinations, but also local tensions and conflicts of interest, can threat the success of AD+ operation.

International tourism competition, for example Italy which is already running successfully the AD model, or internal competition with the existing mountainous lodges and hotels or even more the unequal competition with the well-known sea and sun tourism sector of Greece, threat the operation of an $\mathrm{AD}+$ endeavor. In addition, economic and political issues, such as the continuous changing environment of tax regimes, the discontinuity of political efforts, the slow legislative process and enforcement of legislation and unexpected events like political or/and economic crisis can lead an $\mathrm{AD}+$ to a failure. Moreover, foreign inputs like city and globalised trends can alter local culture and even result to the loss of traditional knowledge, professions and practices. In areas that technology didn't penetrate to the society, the isolation and marginalization of the village is increasing and the gap between the ones who know how to use technology and the ones that don't become bigger.

\section{Discussions}

From the above SWOT analysis it can be seen that many weaknesses are related to political and economic policies. These negative factors could be eliminated if there is political maturity and willingness to take the proper decisions. Li et al., (2016) indicates how actions based on local conditions and context, cooperation, joint goals and strong leadership can manage to unite and raise voices that can be heard and attract external support from businesses and government.

During the pandemic, the $\mathrm{AD}+$ model can target mainly domestic visitors: regular tourists during the weekends and holidays, and remote workers-visitors all year round. However, when the threat of COVID-19 comes to an end, AD+ will really show its potential. Namely it will then be able to attract not only international tourists but also -and perhaps more importantinternational remote workers who wish to enjoy an authentic and attractive environment over longer periods and perhaps even entire seasons where weather conditions in their own countries are hard to come by. In turn, this will give a new life to the village and its local community, beyond the usual summer months of the conventional "sun and sea" model that was followed in Greece for entire decades.

Data from Dologlou (2017) mentions the village of Vamos in the island of Crete, as a known example of participatory dispersed hotel, though not exactly according to AD, which can be seen as a first proof that Greece can indeed support AD. However, we note that Vamos is not located in a remote mountainous area, but is rather situated in a well-known tourism destination.

For such an $\mathrm{AD}+$ project to be successful, suitable destination management and marketing is required because there is strong competition not only between tourism destinations at the regional or national level but at the international level as well. As Pansiri (2014) points out, the process of globalization creates competition even between destinations on opposite sides of the globe. Mountain destinations all over the word offer qualitative agritourism experiences, not to mention the unique AD settlements in neighbouring Italy. The stakes go beyond agritourism. The race is now on for the 'digital nomads' who can work practically from any location in the world. Countries of a sunny disposition, from tax havens to tourist traps, are competing hard to attract this new workforce (Laurent, November 16, 2020). Therefore, future Greek AD+ attempts should focus on their marketing strategy and continuously improve their competiveness and their uniqueness. 
According to Nikas and Tugwell (November 11, 2020), in the spirit of "technology means we can now choose where we live and work", Greece recently announced a program appealing to people able to work from home, giving incentives and a designated framework for workation in Greece. A new legislative and tax framework is ready to be voted as we write, while a $5 \mathrm{G}$ network is scheduled for expansion starting from urban areas and then moving to the rest of the country. At the same time, there is a strong effort to digitally transform public processes and services, improve the fibre landline network and approve investments for Data Centres (Patelis, November 13, 2020). These recent governmental endeavours and strategies are definitely in the right direction and further strengthen the prospects of an AD+ model.

However, additional political measures are needed. The Greek legislation related to tourism should officially set standards and recognize the $\mathrm{AD}+$ structure as a form of tourist accommodation that explicitly enables long-term stays for remote work. Going beyond the existing AD framework of Italy, such legislation should include special requirements and incentives to support environment friendly renovations, operations and services, as well as the design of workspaces that support the remote working aspect of the AD+ model. Moreover, we believe that the government should: improve the Internet connectivity of mountain areas; offer free training to computer and Internet use; subsidize youth online training and education; provide e-training on tourism services; support telemedicine; and give motivation to citizens to remote work from villages. If this opportunity is lost, these areas could be even more marginalised.

Ideally, an $\mathrm{AD}+$ hotel could be developed in a traditional village, which is not very remote, is not yet a very popular mountain tourism destination, but still has enough local population, young inhabitants, natural and cultural resources and traditional buildings. The greatest potential is in traditional hamlets that have already entered a process of regeneration and have managed to activate and engage the local community, probably the biggest challenge of all.

To lay the groundwork of a successful AD+ implementation, one has to conduct interviews with the local population, stakeholders and tourists of the target region in order to identify the interdependencies and interrelations of the concrete human, cultural and natural resources, and to refine the factors identified in the presented SWOT analysis. An expert evaluation should follow, using multi criteria weighting techniques to capture the specifics and peculiarities of each target area.

\section{Conclusion}

The pandemic has brought about tremendous changes, at a scale and speed no one could have anticipated. It is now the time, more than ever, to react and take the opportunity to redesign the tourism and wider developmental plans of mountain areas in order to enhance working and living conditions. This should be driven primarily by the local citizens, to find the new identity of the villages through their history and through the creative application of green technology and innovation.

As a step in this direction, we propose the $\mathrm{AD}+$ model as a new vehicle for achieving sustainable and eco-friendly development for Greek mountain villages, supporting their revival and improving the life of the local communities. For the visitor, $\mathrm{AD}+$ can be the perfect setup for remote work or just an escape for mental relaxation, with the added bonus of becoming part of the local community and experience a unique experience of true hospitality in the village. Ideally, all local stakeholders should participate in an open and honest brainstorming process in 
order to gain a holistic comprehension about the potential of an $\mathrm{AD}+$ establishment in a given target area. We believe that the SWOT analysis presented in this article can serve as a valuable guideline for such a process. Last but not least, the government can substantially contribute to such efforts, through a suitably designed legislative and financing framework.

\section{Resources}

1. Accordino, J., \& Johnson, G.T., 2000. Addressing the Vacant and Abandoned Property Problem, Journal of Urban Affairs, 22(3), 301-315. DOI: 10.1111/0735-2166.00058.

2. Adiyia, B., \& Vanneste, D., 2018. Local tourism value chain linkages as pro-poor tools for regional development in Western Uganda. Development Southern Africa 35(2), 210- 224. DOI: 10.1080/0376835X.2018.1428529.

3. Albergo Diffusi Association [Adi], n.d. Scattered hotels in Italy. Retrieved November 7, 2020 from http://www.alberghidiffusi.it/how-to-join/?lang=en.

4. Ateljevic, I., 2020. Transforming the (tourism) world for good and (re) generating the potential 'new normal'. Tourism Geographies, 22(3), 467-475. DOI: 10.1080/14616688.2020.1759134.

5. Bartik, A.W., Cullen Z.B., Glaeser, E.L., Luca, M., \& Stanton, C.T., 2020. What Jobs are Being Done at Home During the Covid-19 Crisis? Evidence from Firm-Level Surveys. NBER Working Article flow text No. 27422. DOI 10.3386/w27422.

6. Belzunegui-Eraso, A., \& Erro-Garcés, A., 2020. Teleworking in the Context of the Covid-19 Crisis. Sustainability, 12(9). DOI:10.3390/su12093662.

7. Bonzanigo, L., Giupponi, C., \& Balbi, S., 2016. Sustainable tourism planning and climate change adaptation in the Alps: a case study of winter tourism in mountain communities in the Dolomites, Journal of Sustainable Tourism, 24(4), 637-652, DOI: 10.1080/09669582.2015.1122013.

8. Brouder, P., 2020. Reset redux: possible evolutionary pathways towards the transformation of tourism in a COVID-19 world. Tourism Geographies, 22(3), 484-490. DOI: 10.1080/14616688. 2020.1760928.

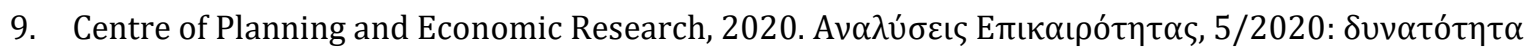

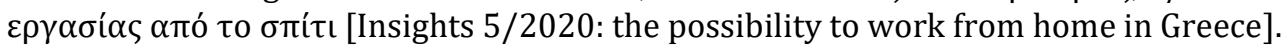

10. Cheer, J. M., 2020. Human flourishing, tourism transformation and COVID-19: a conceptual touchstone. Tourism Geographies, 22(3), 514-524. DOI: 10.1080/14616688.2020.1765016.

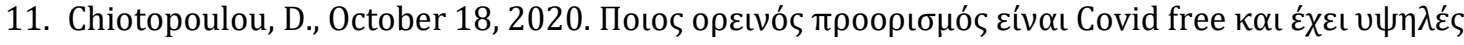
$\pi \lambda \eta \rho$ ó $\rceil \tau \varepsilon$; [Which mountain destination is Covid free and has high occupancy?], GrTimes, https://www.grtimes.gr/ellada/poios-oreinos-proorismos-einai-covid-free-kai-echei?_route_ =ellada/poios-oreinos-proorismos-einai-covid-free-kai-echei (accessed on 16 April, 2021).

12. Christakis, N., 2020, October 16. The long shadow of the pandemic 2024 and beyond. The Wall Street Journal. https://www.wsj.com/articles/the-long-shadow-of-the-pandemic-2024-and-beyond11602860214 (accessed on 16 April, 2021).

13. Christou, P., \& Sharpley, R., 2019. Philoxenia offered to tourists? A Rural Tourism Perspective. Tourism Management, 72, 39-51. https://doi.org/10.1016/j.tourman.2018.11.007.

14. Cucari, N., Wankowiczb, E., \& De Falco, S. E., 2019. Rural tourism and Albergo Diffuso: A case study for sustainable land-use Planning. Land Use Policy, 82, 105-119. https://doi.org/10.1016/j.landusepol. 2018.11.050.

15. Dall'Ara, G., \& Villani, T., 2015. Albergo Diffuso as a model of original hospitality and sustainable development of small historical villages. TECHNE, Journal of Technology for Architecture and Environment, 10, 169-178. DOI: https://doi.org/10.13128/Techne-17513.

16. Dall'Ara G., 2019. Alberghi Diffusi: a worldwide model of Italian Hospitality. Associazione Internationale Alberghi Diffusi. Retrieved from: https://www.slideshare.net/dallara/albergodiffuso-a-worldwide-model-of-italian-hospitality.

17. Debarbieux, B., Oiry Varacca, M., Rudaz, G., Maselli, D., Kohler, T., \& Jurek, M. (eds.), 2014. Tourism in Mountain Regions: Hopes, Fears and Realities. Sustainable Mountain Development Series. Geneva, Switzerland: UNIGE, CDE, SDC, 108.

18. Demir, S., Esbah, H., \& Akhun, A.A., 2016. Quantitative SWOT analysis for prioritizing ecotourismplanning decisions in protected areas: Igneada case, International Journal of Sustainable Development \& World Ecology, 23(5), 456-468, DOI: 10.1080/13504509.2015.1136709.

19. De Montis, A., Ledda, A., Ganciu, A., Serra, V., \& De Montis, S., 2015. Recovery of rural centres and "albergo diffuso": A case study in Sardinia, Italy. Land Use Policy, 47, 12-28. https://doi.org/10.1016/j.landusepol.2015.03.003. 
20. Di Gregorio, D., 2017. Place-based business models for resilient local economies: Cases from Italian slow food, agritourism and the albergo diffuso. Journal of Enterprising Communities: Peopleand Placesin the GlobalEconomy, 11 (1), 113-128. https://doi.org/10.1108/JEC-02-2015-0016.

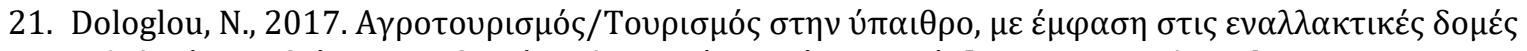

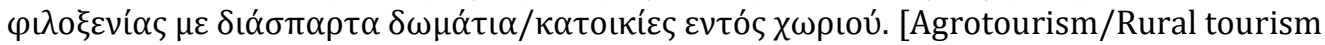
with emphasis in alternative philoxenia of the Albergo Diffuso model]. Research study in the framework of the programme "modern trends of tourism in EU and Greece". Jean Monned European Centre of Excellence, University of Athens, November 2016.

22. Dyson, R. G., 2004. Strategic Development and SWOT Analysis at the University of Warwick, European Journal of Operational Research, 152(3), 631-640.

23. Dropulić, M., Krajnović, A., \& Ružić, P., 2008. Albergo Diffuso Hotels - A Solution to Sustainable Development of Tourism. 27th International Conference on Organizational Science Development Knowledge for sustainable development. March 19-21, 2008, Portorož, Slovenia, https://bib.irb.hr/datoteka/361120.077Dropulic.pdf (accessed on 20 October, 2020)

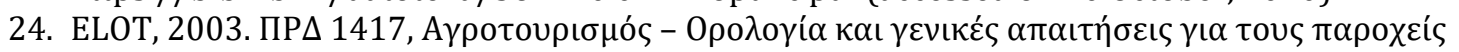

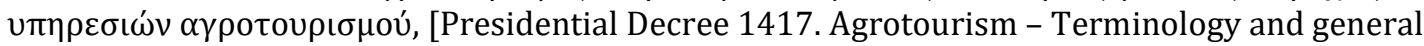
requirements for the agrotourism service providers]. Hellenic Body for Standardisation Athens (ELOT), Greece.

25. Eurofound, 2010. Telework in the European Union, Publications Office of the European Union, Luxembourg.

26. Eurofound and the International Labour Office, 2017. Working anytime, anywhere: The effects on the world of work, Publications Office of the European Union, Luxembourg, and the International Labour Office, Geneva.

27. Eurofound. (2020, September 28), Living, working and COVID-19 dataset, Dublin, https://www.eurofound.europa.eu/data/covid-19 (accessed on 16 April, 2021)

28. European Ecotourism Network, n.d. The European Ecotourism Labelling Staandard - EETLS http://www.ecotourism-network.eu/en-ecotourism-standard/en-the-euro-eco-label-stand (accessed on 1 December, 2020).

29. Felstead, A., \& Reuschke, D., 2020. Homeworking in the UK: before and during the 2020 lockdown, WISERD Report, Cardiff: Wales Institute of Social and Economic Research.

30. FAO, 2020. International Mountain Day, theme 2020. Food and Agriculture Organization of the United Nations (FAO), http://www.fao.org/international-mountain-day/theme/2020/en/ (accessed on 16 April, 2021).

31. Fougere, K.T., \& Behling, R.P., 1996. Telecommuting is Changing the Definition of the Workplace, Journal of Computer Information Systems, 36(2), 26- 29, DOI: 10.1080/08874417.1996.11647188.

32. Giampiccoli, A., \& Mtapuri, O., 2020. Towards a coalescence of the community-based tourism and 'Albergo Difusso' tourism models for Sustainable Local Economic Development. African Journal of Hospitality, Tourism and Leisure, 9(1), 657-667.

33. Goffman, E., 2020. In the wake of COVID-19, is globalization our sustainability future? Sustainability: Science, Practice and Policy, 16(1), 48-52. DOI: 10.1080/15487733.2020.1765678.

34. Goranczewski, B., \& Puciato, D., 2010. SWOT Analysis in the Formulation of Tourism Development Strategies for Destinations. Tourism, 20(2). DOI: 10.2478/v10106-010-0008-7.

35. Gössling S., Scott D., \& Hall, C.M., 2021. Pandemics, tourism and global change: a rapid assessment of COVID-19, Journal of Sustainable Tourism, 29(1), 1-20, DOI: 10.1080/09669582.2020.1758708.

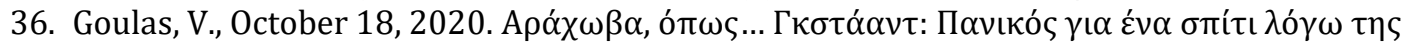
$\pi \alpha v \delta \eta \mu i \alpha$ s, [Arachova as ... Gstaad: Panic for a house due to the pandemic], newspaper: protothema, https://www.protothema.gr/travelling/article/1056217/arahova-opos-gstaad-panikos-gia-enaspiti-logo-tis-pandimias/ (accessed on 29 November, 2020).

37. Hall, C. M., Scott, D., \& Gössling, S., 2020. Pandemics, transformations and tourism: be careful what you wish for. Tourism Geographies, 22(3), 577-598. DOI: 10.1080/14616688.2020.1759131.

38. Higgins-Desbiolles, F., 2020. The "war over tourism": challenges to sustainable tourism in the tourism academy after COVID-19, Journal of Sustainable Tourism. DOI: 10.1080/09669582.2020. 1803334.

39. Hung, K., 2013. Understanding China's Hotel Industry: A SWOT Analysis, Journal of China Tourism Research, 9(1), 81-93, DOI: 10.1080/19388160.2013.756771. 
40. Jacobs, L., Du Preez E.A., \& Fairer-Wessels, F., 2020. To wish upon a star: Exploring Astro Tourism as vehicle for sustainable rural development, Development Southern Africa, 37(1), 87-104, DOI: 10.1080/0376835X.2019.1609908.

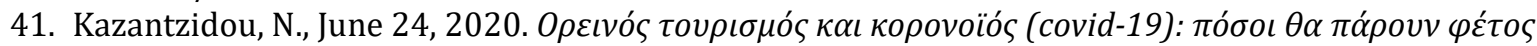
$\tau \alpha$ ßovvó; [Mountain tourism and the coronavirus (covid-19): how many will go to the mountains this year?]. Athens News Agency - Macedonian Press Agency (ANA-MPA), https://www.amna.gr/tourism/article/468394/Oreinos-tourismos-kai-koronoios-covid-19--Posoitha-paroun-fetos-ta-bounarn (accessed on 29 January, 2021).

42. Kim, S., Lee, J., \& Jung, J., 2013. Assessment of Medical Tourism Development in Korea for the Achievement of Competitive Advantages, Asia Pacific Journal of Tourism Research, 18(5), 421445, DOI: $10.1080 / 10941665.2012 .658416$.

43. Koroneos C. J. \& Rokos D., 2012. Sustainable and Integrated Development-A Critical Analysis, Sustainability, 4, 141-153, http://doi:10.3390/su4010141.

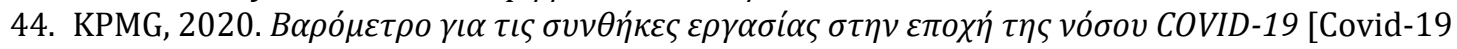
Employment Conditions Barometer Report for Greece], KPMG Certified Auditors S.A, April 2020

45. Lak, A., Gheitasi, M., \& Timothy, D.J., 2020. Urban regeneration through heritage tourism: cultural policies and strategic management, Journal of Tourism and Cultural Change, 18(4), 386-403, DOI: $10.1080 / 14766825.2019 .1668002$.

46. Laurent, L., November 16, 2020. Bloomberg: WFH in Greece or Barbados? The Fight for Covid's Digital Nomads. https://www.bloomberg.com/opinion/articles/2020-11-16/greece-or-barbadosthe-tax-fight-for-covid-s-wfh-nomads-begins (accessed on 20 November, 2020).

47. Li, Y., Westlund, H., Zheng, X., \& Liu, Y., 2016. Bottom-up initiatives and revival in the face of rural decline: Case studies from China and Sweden. Journal of Rural Studies. 47(B), 506-513 https://doi.org/10.1016/j.jrurstud.2016.07.004.

48. Lun, L-M., Pechlaner, H., \& Volgger, M., 2016. Rural Tourism Development in Mountain Regions: Identifying Success Factors, Challenges and Potentials, Journal of Quality Assurance in Hospitality \& Tourism, 17(4), 389-411, DOI: 10.1080/1528008X.2015.1096754.

49. MBO Partners, 2018. State of Independence In America Research Brief. Digital Nomadism: A Rising Trend. Retrieved 13 April from https://s29814.pcdn.co/wpcontent/uploads/2019/02/ StateofIndependence-ResearchBrief-DigitalNomads.pdf.

50. McQuaid, R., Lindsay, C., \& Greig, M., 2004. Reconnecting' the Unemployed Information and communication technology and services for jobseekers in rural areas, Information Communication \& Society, 7(3), 364-388, DOI: 10.1080/1369118042000284605.

51. Mtapuri, O., \& Giampiccoli, A., 2019. Tourism, community-based tourism and ecotourism: a definitional problematic, South African Geographical Journal, 101(1), 22-35, DOI:10.1080/ 03736245.2018 .1522598$.

52. Mtapuri, O., \& Giampiccoli, A., 2020. Towards a Model of Just Tourism: a Proposal. Social Science, Soc. Sci., 9(4), 34. https://doi.org/10.3390/socsci9040034.

53. Nikas, S., \& Tugwell, P., November 11, 2020. Bloomberg: Greece Offers Tax Breaks to Lure the WorkFrom-Anywhere Crowd, https://www.bloomberg.com/news/articles/2020-11-11/greece-seeks-to-lureworkers-from-abroad-with-new-tax-incentives (accessed on 21 November, 2020).

54. Ory, D.D., \& Mokhtarian, P.L., 2006. Which Came First, the Telecommuting or the Residential Relocation? An Empirical Analysis of Causality, Urban Geography, 27(7), 590-609, DOI: 10.2747/ 0272-3638.27.7.590.

55. Paniccia, P.M.A., \& Leoni, L., 2017. Co-evolution in tourism: the case of Albergo Diffuso. Current Issues in Tourism 22(10), 1216-1243, https://doi.org/10.1080/13683500.2017.1367763.

56. Pansiri, J., 2014. Tourist Motives and Destination Competitiveness: A Gap Analysis Perspective, International Journal of Hospitality \& Tourism Administration, 15(3), 217-247, DOI: $10.1080 / 15256480.2014 .925718$.

57. Patelis, A., November 13, 2020. Bloomberg Day Break: Europe: Moody's Raises Greece's Rating as Reforms Bring Progress. https://www.bloomberg.com/news/videos/2020-11-13/moody-s-raisesgreece-s-rating-as-reforms-bring-progress-video (accessed on 21 November, 2020).

58. Patnaik, R., \& Poyyamoli, G., 2015. Developing an eco-industrial park in Puducherry region, India - a SWOT analysis, Journal of Environmental Planning and Management, 58(6), 976-996, DOI: 10.1080/09640568.2014.904768.

59. Pecsek, B., 2018. Working on holiday: the theory and practice of workcation. Balkans Journal of Emerging Trends in Social Sciences, 1(1), DOI: https://doi.org/10.31410/Balkans.JETSS.2018. 1.1.1$\underline{13}$ 
60. Pozoukidou, G., \& Papageorgiou, M., 2013. Protection of traditional settlements in Greece: Legislation and practice. In the proceedings of the International Conference on "Changing Cities". Spacial, morphological, formal and socio-economic dimension. 18-23 June 2013, Skiathos, Greece. 501-510.

61. Pretty, J., Adams, B., Berkes, F., De Athayde, S., Dudley, N., Hunn E., Maffi, L., Milton, K., Rapport, D., Robbins, P., Sterling, E., Stolton, S., Tsing, A., Vintinnerk, E., \& Pilgrim, S., 2009. The intersection of Biological Diversity and Cultural Diversity: Towards Integration. Conservat Soc, 7(2), 100-112.

62. Rasmussen, E., \& Corbett, G., 2008. Why isn't teleworking working? New Zealand Journal of Employment Relations, 33(2), 20-32.

63. Rauniyar, S., Awasthi, M.K., Kapoor, S., \& Mishra, A.K., 2020. Agritourism: structured literature review and bibliometric analysis, Tourism Recreation Research, DOI:10.1080/02508281.2020. 1753913.

64. Rokos, D., 2003. From Sustainable to Worthliving Integrated Development [in Greek] A.A. Livanis Publishing: Athens, Greece, 551.

65. Seyfi, S., \& Hall, C. M., 2020. COVID-19 pandemic, tourism and degrowth. In Hall, C. M., Lundmark, L., \& Zhang, J. (Eds). Degrowth and Tourism: New Perspectives on Tourism Entrepreneurship, Destinations and Policy. Routledge.

66. Soszyński, D., Sowińska-Świerkosz, B., Stokowski, P.A., \& Tucki, A., 2018. Spatial arrangements of tourist villages: implications for the integration of residents and tourists, Tourism Geographies, 20(5), 770-790, DOI: $10.1080 / 14616688.2017 .1387808$.

67. Tagliabue, L. C., Leonforte, F., \& Compostella, J., 2012. Renovation of an UNESCO heritage settlement in southern Italy: ASHP and BIPV for a "Spread Hotel" project. Energy Procedia, 30, 1060-1068 https://doi.org/10.1016/j.egypro.2012.11.119.

68. UNWTO, 2020. AlUla framework for Inclusive Community Development through Tourism. Madrid, United Nation World Tourism Organisation (UNWTO), https://doi.org/10.18111/9789284422135

69. Vallone, C., Orlandini, P., \& Cecchetti, R.l., 2013. Sustainability innovation in Tourism Services: the AD case Study. Eurasian Journal of Social Science, 1(2), 21-34.

70. Vilhelmson, B., \& Thulin, E., 2016. Who and where are the flexible workers? Exploring the current diffusion of telework in Sweden, New Technology, Work and Employment, 31(1) 77-96.

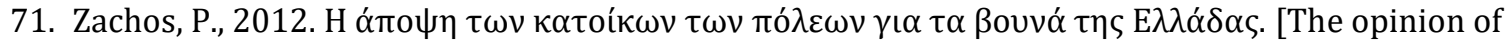
urban residents for the Greek mountains]. Postgraduate Programme (2 ${ }^{\text {nd }}$ stream) Environment and Development of Mountain Regions, National Technical University of Athens, Metsovo, Greece

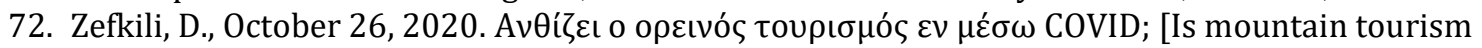
flourishing during COVID?], https://www.athinorama.gr/travel/travelideas/articles.aspx?artid= 2545292_(accessed on 29 November, 2020).

(C) 2021 by the authors. Submitted for possible open access publication under the terms and conditions of the Creative Commons Attribution-Non Commercial-No Derivatives (CC BY NC ND) $4.0 \quad$ International License. (https://creativecommons.org/licenses/by-nc-nd/4.0/). 